\title{
Experience of elders on elder abuse
}

\author{
Ms. Aysha K, ${ }^{1}$,Ms. Helen Alosious ${ }^{2}$, Ms. Ditty Davis ${ }^{3}$ Ms.Ayisha Parveen, ${ }^{4}$ \\ Mrs.Benazeera,Lecturer ${ }^{5}$ \\ ${ }^{1,2,3,4} I V^{\text {th }}$ yr students, Yenepoya Nursing college, Yenepoya University,India \\ ${ }^{5}$ Dept. Paediatric Nursing, Yenepoya Nursing college, Yenepoya University
}

\begin{abstract}
Long life is a sign of good health; and aging is a natural process that influences the individual, family and society in different ways. Ageing is not disease but the final stage of normal life. The ageing of the world's population in developing and developed countries is an indicator of improving global health ${ }^{1}$.The research design adopted for the study was descriptive research design. The study was conducted in selected old age home at Mangaluru. The sample comprised of 100 elders who were selected using purposive sampling technique. Demographic proforma, structured checklist for assessing the experience of elder abuse were used to collect the data. Descriptive and inferential statistics were adopted to analysis the data. Result: [67.25\%] of samples were ignored by family members, [63.3\%] of samples are physically abused, [58\%] of samples are emotionally abused, [46\%] of samples are financially abused and [7.5\%] of samples are sexually abused, which were based on the experience of the elder's on elder abuse. The study concluded that majority of the elder experienced about negligence and physical abuse from family members. Hence systematic education, training and coordinated efforts is needed across all relevant field to preserve and protect the elder from elder abuse.
\end{abstract}

Keywords: Elder, Elder abuse, Experience.

\section{Introduction}

While family violence and child abuse have received considerable attention in the past, only in the last decade has elder abuse emerged as an area for concern. As the population of older people expands, there is increasing urgency to deal with and address the issues of abuse and mistreatment of older people ${ }^{3}$. Aging is not a disease but the final stage of normal life. Old age is an incurable disease ${ }^{4}$. Old age is not an accident; it is an unavoidable incident of life. As age increases physiological and psychological functions also get aged ${ }^{5}$.

As the population continues to age, elder abuse is an issue that must not be ignored, although elder abuse is entirely a new issue. It is time for a unified definition to be identified. Aging is progressive state beginning with consumption and ending with death which is associated with physical, social, and psychological changes, there has been considerable increase in the absolute and relative number of elderly in the world ${ }^{6}$.

Although elder abuse has existed throughout time, only in the most recent decades have researchers and literature begun seriously to address the issue. As a flux of recent research and literature indicate, Elders are like children with their mood swings, sometimes too quickly not allowing us enough time to grasp. Elders need attention at homes and if we don't give it, they start demanding it. When the elders begin to feel they are neglected, they adopt ways to attract attention from us and at times irritating. Mental agitation, restlessness, Falling sick often, nausea, vomiting and even suicide attempts could be just reactions to this neglect by family members ${ }^{7}$.

\section{Material And Methods}

Research design selected to carry out the study was descriptive research design. The study was conducted in selected old age home at Mangaluru, and 100 samples were recruited by using non- purposive sampling technique. Prior to the data collection, permission was obtained from the concerned authority for conducting the study. Distribution of demographic proforma and experience of elder abuse was assessed by assessment tool done for the participants. The reliability of the tool was tested by split half method. The investigator was conducted pilot study prior to the main study. The participants were explained and consent was obtained from the study participants. The participants were assured about the confidentiality of their responses. Data was analysed by using descriptive and inferential statistics.

\section{Result}

\subsection{Demographic proforma}

Majority [51\%] of elders belongs to the age group of $60-70$ years and [58\%] of elders are females , [67\%] are married , [50\%] of elders have primary education ,[66\%] belongs to Christian religion, [53\%] belongs to nuclear family, [57\%] of their children are working in India , [51\%] of elders are residing in rural area, [65\%] of elders are belongs to average income family. 


\section{2experience Of Elder Abuse Among Elders}

Table 1: shows the overall mean, median, mode, standard deviation, mean percentage of experience of elder abuse among elders:

$\mathrm{n}=100$

\begin{tabular}{|l|l|l|l|l|l|l|l|l|}
\hline $\begin{array}{l}\text { Sl. } \\
\text { NO. }\end{array}$ & $\begin{array}{l}\text { TYPE OF } \\
\text { ABUSE }\end{array}$ & $\begin{array}{l}\text { MAX POSSIBLE } \\
\text { SCORE }\end{array}$ & RANGE & MEAN & MEDIAN & MODE & SD & $\begin{array}{l}\text { MEAN } \\
\%\end{array}$ \\
\hline 1 & Physical abuse & 3 & 3 & 1.9 & 2 & 2.0 & 1.37 & $63.3 \%$ \\
\hline 2 & $\begin{array}{l}\text { Financial } \\
\text { Abuse }\end{array}$ & 4 & 4 & 1.6 & 1.0 & 1.0 & 1.79 & $46 \%$ \\
\hline 3 & $\begin{array}{l}\text { Emotional } \\
\text { Abuse }\end{array}$ & 5 & 5 & 2.9 & 4.0 & 4.0 & 2.44 & $58 \%$ \\
\hline 4 & $\begin{array}{l}\text { Neglect } \\
\text { Abuse }\end{array}$ & 4 & 4 & 1.73 & 1.0 & 1.0 & 1.85 & $67.25 \%$ \\
\hline 5 & $\begin{array}{l}\text { Sexual } \\
\text { Abuse }\end{array}$ & 4 & 4 & 0.3 & .00 & .00 & 0.98 & $7.5 \%$ \\
\hline & TOTAL & 20 & 20 & 8.43 & 8 & 8 & 8.43 & 242.05 \\
\hline
\end{tabular}

Table 1: The subject data showed that the mean percentage of experience of elder's on elder abuse among samples, the maximum mean percentage [67.25\%] of samples were ignored by family members, [63.3\%] of samples are physically abused, [58\%] of samples are emotionally abused, [46\%] of samples are financially abused and [7.5\%] of samples are expressed about sexual abuse.

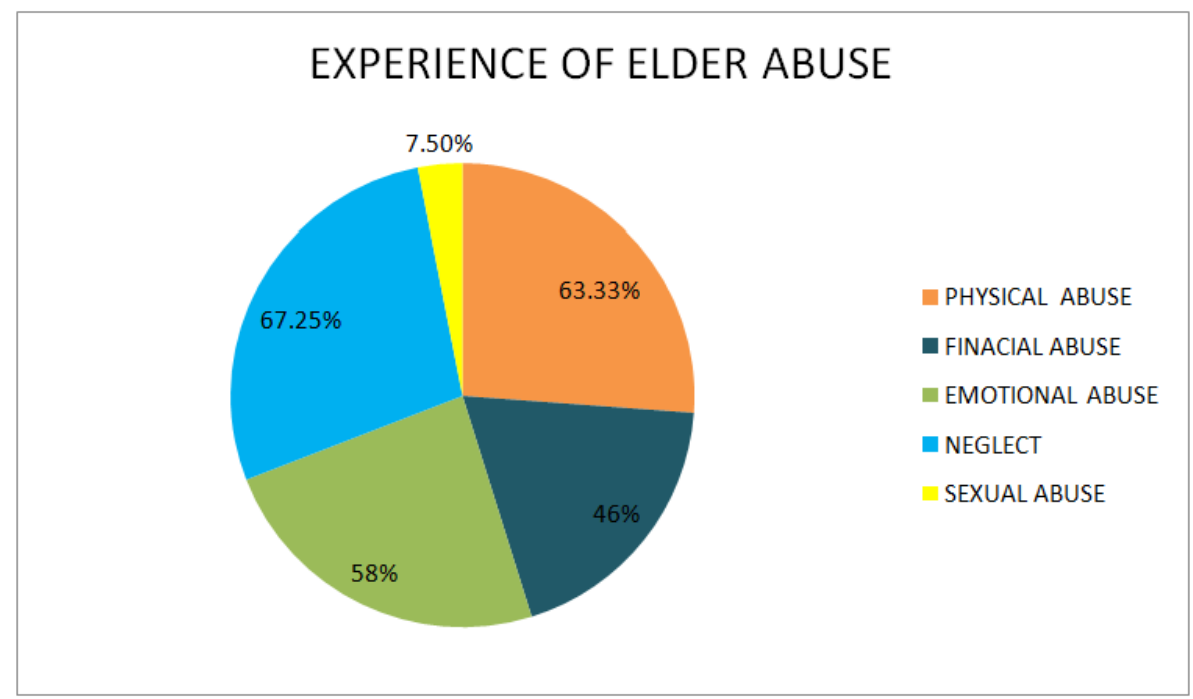

Fig 1: Pie showing the experience of elder abuse

The mean percentage of experience of elder abuse among samples, the maximum mean percentage [67.25\%] of samples were ignored by family members, [63.3\%] of samples are physically abused, [58\%] of samples are emotionally abused, [46\%] of samples are financially abused and [7.5\%] of samples are expressed about sexual abuse

\section{3association Between Experience And Demographic Variables}

Tables 2: Association between experience of elder abuse and selected demographic variables.n=100

\begin{tabular}{|c|c|c|c|}
\hline SI.NO. & VARIABLES & +2 & CHI-SQUARE $\left[\chi^{2}\right]$ \\
\hline 1 & $\begin{array}{cl}\text { Age in years } \\
\text { a. } & 60-70 \\
\text { b. } & 71-80 \\
\text { c. } & 81-90 \\
\text { d. } & 91-100\end{array}$ & 3 & $\begin{array}{l}* 8.911 \\
\mathrm{P}=7.82\end{array}$ \\
\hline 2 & $\begin{array}{cl}\text { Gender } & \\
\text { a. } & \text { Male } \\
\text { b. } & \text { Female } \\
\end{array}$ & 1 & $\begin{array}{l}* 11.74 \\
\mathrm{P}=3.84\end{array}$ \\
\hline 3 & \begin{tabular}{cl}
\multicolumn{3}{c}{ Marital status } \\
$\begin{aligned} \text { a. } & \text { single } \\
\text { b. } & \text { married } \\
\text { c. } & \text { widow }\end{aligned}$
\end{tabular} & 2 & $\begin{array}{l}* 7.68 \\
P=5.99\end{array}$ \\
\hline 4 & \begin{tabular}{ll}
\multicolumn{3}{l}{ Education } \\
a. primary education \\
b. higher secondary
\end{tabular} & & \\
\hline
\end{tabular}




\begin{tabular}{|c|c|c|c|}
\hline & $\begin{array}{ll}\text { c. } & \text { pre-university } \\
\text { d. } & \text { graduate and above } \\
\text { e. } & \text { no formal education }\end{array}$ & 3 & $\begin{array}{l}* 10.25 \\
\mathrm{P}=7.82\end{array}$ \\
\hline 5 & $\begin{array}{l}\text { Type of family } \\
\text { a. nuclear family } \\
\text { b. joint family } \\
\text { c. extended family }\end{array}$ & 2 & $\begin{array}{l}* 11.22 \\
\mathrm{P}=5.99\end{array}$ \\
\hline
\end{tabular}

The data presented in table 2 shows that there is a significant association between experience of elder abuse and demographic variables, age in years $\mathrm{x}^{2}(3)=8.911$, gender $\mathrm{x}^{2}(1)=11.74$, marital status $\mathrm{x}^{2}(2)=7.68$, education $\mathrm{x}^{2}(3)=10.25$, type of family $\mathrm{x}^{2}(2)=11.22$ the demographic. Hence the research hypothesis is accepted for the same variables.

\section{Discussion}

The experience of elder abuse among samples, [67.25\%] of samples are ignored by family members, [63.3\%] of samples are physically abused, [58\%] of samples are emotionally abused, [46\%] of samples are financially abused and [7.5\%] of samples are sexually abused, which were based on the experience of the elder's on elder abuse. A similar study was conducted in US analysis the experience of different forms of abuse. The study revealed that elders are experienced financial exploitation (20.8\%), emotional or psychological abuse (13.9\%), physical abuse (12.5\%) and sexual abuse (0.7\%). Among abused elders females accounted for (65.7\%) and age wise $(42.8 \%)$ of victims were 80 years and older ${ }^{8}$.

\section{Conclusion}

This study found that majority of the elder experienced about negligence and physical abuse from family members. Hence systematic education, training and coordinated efforts is needed across all relevant field to preserve and protect the elder from elder abuse.

\section{Reference}

[1]. WHO. Health topics. Ageing.2011 April 7: http://www.who.int/en.

[2]. K. park, parks text book of preventive and social medicine. 19 $9^{\text {th }}$ ed; 2007: 475-76.

[3]. Treacy J, Drenna N, Phelan A, Quin S. Public Perception of elder abuse: A literature review. J Gerontology. 2009 ; 13 (1) 32-6.

[4]. Oldage.2015 June7: http://www.who.int/healthinfo/survey/agingdefnolder/en/index.html;//

[5]. Living with old age and stress. 2006 Apr 6: http://www.healthguaidance.org/entry/5580/1/living-with-old-age-and-stress-html

[6]. Mary A, Wyandt, Californian. Perception of elder abuse: A Literature review. J Health Promotion 2004; 2(3)40-50.

[7]. R.Sreevani, mental health and psychiatric nursing. $2^{\text {nd }}$ ed: Jaypee Brothers Publishers; 2004:246-48.

[8]. Hokenstad, M.C.T Jr, Roberts, AR. International policy on aging and older persons: Implication for social work practice.2011;54(3):330-43. 